\title{
PENGARUH ORIENTASI KEWIRAUSAHAAN DAN AKSES KEUANGAN TERHADAP KINERJA USAHA
}

\author{
Muchammad Rizki Agung Putra, Nila Firdausi Nuzula, Muhammad Khalid Mawardi \\ Fakultas Ilmu Administrasi, Universitas Brawijaya, Malang, Indonesia \\ E-mail: rizkipuutra@gmail.com,nila_fia@ub.ac.id,mawardi_fia@ub.ac.id
}

\begin{abstract}
This study attempts to explain the influence of orientation entrepreneurship and financial access on their performance. Business research by analyzing the effectiveness of the KUR program bri given to the offender SME's in Blitar East Java. With a technique, the sample collection non-probability in random proportionate, with the data was path analysis. The result showed that orientation entrepreneurship positive effect on access to finance, entrepreneurial orientation also has a relationship significantly to the performance of businesses either directly or indirectly financial access addition, financial access to depend on the performance of business.
\end{abstract}

Keywords: Entrepreneurship Orientation, Financial Acces, Business Performance, SME's.

\begin{abstract}
ABSTRAK
Penelitian ini bertujuan untuk menjelaskan pengaruh dari orientasi kewirausahaan dan akses keuangan terhadap kinerja usaha. Penelitian dengan menganalisis efektifitas program KUR BRI yang diberikan pada pelaku UMKM di wilayah Kota Blitar, Jawa timur. Dengan teknik pengambilan sampel nonprobability secara random proporsional, dengan teknik analisis data yaitu analisis jalur (Path Analys). Hasil penelitian menunjukkan bahwa orientasi kewirausahaan berpengaruh positif terhadap akses keuangan, orientasi kewirausahaan juga memiliki hubungan signifikan terhadap kinerja usaha baik secara langsung maupun tidak langsung melalui akses keuangan. Selain itu, akses keuangan juga berpengaruh terhadap kinerja usaha.
\end{abstract}

Kata Kunci: Orientasi Kewirausahaan, Akses Keuangan, Kinerja Usaha, UMKM. 


\section{PENDAHULUAN}

Dengan munculnya globalisasi, lingkungan bisnis menjadi semakin tidak pasti dan kompleks. Lingkungan berubah terusmenerus dan cepat. UMKM dipaksa untuk mempelajari pengetahuan baru untuk mengembangkan produk atau kinerja. Dengan demikian UMKM mengejar pengetahuan kewirausahaan agar dapat mencapai keunggulan kompetitif. Dari perspektif berbasis sumber daya (RBV), orientasi kewirausahaan merupakan orientasi strategis yang terpisah tetapi saling melengkapi sebagai suatu strategi. orientasi kewirausahaan menekankan filosofi dan perilaku dalam mendeteksi lingkungan industri secara proaktif, termasuk informasi pasar dan strategi pesaing untuk berinovasi dan menanggapi kebutuhan pelanggan. Sifat orientasi kewirausahaan sangat ditekankan pada kesediaan UMKM untuk berinovasi di dalamnya (Marus et al.,2017). Inovasi dalam hal ini tidak hanya membuat produk baru akan tetapi inovasi dalam akses informasi atau akses keuangan melalui permodalan. UMKM di Indonesia pada umumnya berhubungan erat dengan akses permodalan atau dukungan keuangan berupa pinjaman berbunga (leverage) yang menjadi seperti pertimbangan penting untuk menunjang kinerja perluasan pasar atau peningkatan produksi dibutuhkan modal kerja finansial yang besar, akan tetapi ketika terjadi penurunan kinerja atau bahkan pailit, hal itu pula yang menjadi penghadang utama bagi kelangsungan hidup UMKM.

Menurut Marus et al.,(2017) minimnya aset dan fondasi keuangan yang lemah sering menyulitkan UMKM secara global untuk melakukan dan memperluas pangsa pasar, akibatnya modal ekuitas yang tidak memadai yang diinvestasikan dalam UMKM membuat bisnis ini lebih bergantung pada sumber lain seperti pinjaman bank dan jenis kredit keuangan lainnya. Sebagian besar UKM bergantung pada pembiayaan internal atau jasa lembaga keuangan khusus. Pinjaman internal terkadang melibatkan suntikan modal baru dari tabungan pribadi pemilik, dan laba ditahan atau tidak terdistribusi dari bisnis yang diperoleh pada tahun-tahun sebelumnya. Akses ke kredit tetap menjadi kendala bagi UMKM dalam hal modal kerja. UMKM memiliki akses terbatas ke pasar modal, lokal dan internasional, sebagian karena persepsi risiko yang lebih tinggi, hambatan informasi, dan biaya perantara yang lebih tinggi menghambat pertumbuhan dan daya saing (Mason et al.,2015). Berbagai hal tersebut yang menyebabkan UMKM di Indonesia mengalami kesulitan dalam ekspansi ke level global. Sehingga kinerja usaha baik secara finansial dan non-finansial turut menjadi masalah yang dihadapi UMKM.

Salah satu bank pemerintah tertua dan menjadi pelopor dalam pemberian kredit adalah Bank Rakyat Indonesia (BRI). Pada akhir tahun 2019 pemerintah menunjuk BRI sebagai salah satu bank dengan target penyaluran KUR terbesar yakni Rp 21,4 triliun dengan rincian KUR Mikro Rp 17 triliun, KUR Ritel Rp 4 triliun, dan KUR TKI Rp 400 miliar. Sehingga diharapkan efektifitas KUR BRI mampu menjadi penopang modal untuk UMKM meningkatkan kinerja usaha. Selain itu, penelitian ini menjelaskan hubungan gap penelitian yang terdiri dari Menurut Mason et al.,(2015) hutang usaha sebagai bagian risiko keuangan perusahaan yang harus dikelola dengan tepat dapat menjadi pendukung kinerja usaha namun juga dapat menjadi beban yang menggangu keberlangsungan usaha, sehingga penelitian tentang dampak hutang pada kinerja perusahaan masih banyak belum disimpulkan (Fatoki, 2012), dengan beberapa penelitian menemukan dampak negatif (Eriotis et al., 2002) sedangkan penelitian lainnya berdampak positif pada peningkatan kinerja (Negash, 2002; Hadlock dan James, 2002).

Karakter lingkungan bisnis baik secara makro ataupun mikro setiap negara yang berbeda membuat kajian efektifitas kredit usaha sebagai pendukung keuangan pada UMKM berbeda pula. Oleh karena itu penelitian ini ingin mengetahui dampak faktor perbedaan antara negara berkembang seperti di Indonesia dengan sesama negara berkembang atau negara maju lain misalnya penelitian Mason et al.,(2015) di negara italia yang membahas tentang moderasi leverage UMKM sebagai penunjang kinerja usaha. Kemudian penelitian Marus et al.,(2012) di negara Uganda yang meneliti tentang dampak kredit usaha terhadap kinerja UMKM yang notabene lebih lemah pertumbuhan ekonominya daripada di Indonesia . 
KAJIAN PUSTAKA

Kewirausahaan dan Orientasi
Kweirausahaan

Kewirausahaan

merupakan

kemampuan kreatif dan inovatif yang dijadikan dasar, dan sumber daya untuk mencari peluang menuju kesuksesan. Beberapa literatur manajemen memberikan tiga landasan dimensi dari kecenderungan organisasional untuk proses manajemen kewirausahaan, yakni kemampuan inovasi, kemampuan mengambil risiko, dan sifat proaktif. Menurut Sigauw et al.,(1998), kompetensi kewirausahaan dibutuhkan didalam implementasi strategi pemasaran agar diperoleh keunggulan bersaing yang mantap melalui nilai responsifitas atas kebutuhan pelanggan. Sedangkan jiwa kewirausahaan sendiri meliputi 5 hal, yakni: otonomi, keinovatifan, pengambilan risiko, proaktivitas, dan agresifitas kompetitif. Menurut Kottler (2001), pemasaran entrepreneurial merupakan sebuah konsep yang terpadu diera penuh perubahan seperti sekarang ini. Pemasaran entrepreneurial sendiri didefinisikan oleh Morris dan Lewis (2002) sebagai sebuah aktifitas mengidentifikasi secara proaktif upaya mencapai dan mempertahankan pelanggan yang memberikan keuntungan melalui pendekatan yang inovatif terhadap manajemen risiko, efektifitas sumber daya, dan pengembangan nilai.

(Lumpkin \& Dess, 1996) mengusulkan lima dimensi Entrepeneurial Orientation atau Orientasi Kewirausahaan: Autonomy atau otonomi, Risk-taking atau pengambilan risiko, Proactiveness atau proaktif, dan Competitive Aggressiveness atau agresivitas kompetitif. Dengan kata lain, menambahkan dua dimensi tambahan yaitu otonomi dan agresivitas kompetitif untuk tiga dimensi yang diusulkan oleh Miller (1983). Penelitian ini juga membahas variable akses keuangan berupa kredit. Kredit adalah penyediaan uang atau tagihan yang dapat disamakan dengan itu, berdasarkan persetujuan atau kesepakatan pinjam-meminjam atara bank dengan pihak lain yang mewajibkan pihak peminjam untuk melunasi utangnya setelah jangka waktu tertentu dengan pemberian bunga.

\section{Akses Keuangan UMKM}

Beberapa tujuan kredit adalah dalam pendekatan mikro ekonomi, tujuan pemberian kredit guna mendapatkan suatu nilai tambah baik bagi nasabah (debitur) maupun bagi bank sebagai kreditur. Bagi nasabah sebagai debitur dengan mendapatkan kredit bertujuan untuk mengatasi kesulitan pembiayaan dan meningkatkan usaha dan pendapatan dimasa depan. Bagi bank sendiri juga diharapkan melalui pemberian kredit akan menghasilkan pendapatan bunga sebagai pengganti harga dari pinjaman itu sendiri. Dalam pendekatan makro ekonomi pemberian kredit merupakan salah satu instrumen untuk menjaga keseimbangan jumlah uang beredar di masyarakat.

Sedangkan kredit salah satu jenis adalah kredit usaha rakyat (KUR) adalah kredit/ pembiayaan kepada Usaha Mikro Kecil Menengah Koperasi (UMKM-K) dalam bentuk pemberian modal kerja dan investasi yang didukung fasilitas penjaminan untuk usaha produktif. KUR adalah program yang dicanangkan oleh pemerintah namun sumber dananya berasal sepenuhnya dari dana bank. Pemerintah memberikan penjaminan terhadap resiko KUR sebesar $70 \%$ sementara sisanya sebesar 30\% ditanggung oleh bank pelaksana. Penjaminan KUR diberikan dalam rangka meningkatkan akses UMKM-K pada sumber pembiayaan dalam rangka mendorong pertumbuhan ekonomi nasional.

\section{Kinerja Usaha}

Tujuan perusahaan yang terdiri dari: tetap berdiri atau eksis (Survive), untuk meperoleh laba (Benefit), dan dapat berkembang (Growth), dapat tercapai apaila perusahaan tersebut mempunyai performa yang baik. Kinerja (Performance) perusahaan dapat dilihat dari tingkat penjualan, tingkat keuntungan, pengembalian modal, tingkat turn over dan pangsa pasar yang diraihnya (Jauch dan Glueck (1988).

Pertumbuhan penjualan (Sales growth), pertumbuhan tenaga kerja (Employment growth), pertumbuhan pendapatan (Income growth) dan pertumbuhan pangsa pasar (Market share growth) sebagai pengukuran kinerja perusahaan kecil yang paling penting (Ontorael, 2017). Hal ini juga didasarkan pada argumentasi bahwa pertumbuhan adalah indikator yang lebih tepat dan mudah diperoleh dibandingkan dengan indikator kinerja keuangan. Pendapat alternatif lain adalah bahwa kinerja bersifat multidimensional dan oleh karena itu hal ini berguna untuk mengintegrasikan dimensi yang berbeda dari kinerja dalam suatu studi empiris (Lumkin dan Dess,1996). Adalah tepat untuk 
melihat kinerja keuangan dan pertumbuhan sebagai aspek berbeda dari kinerja, dimana masing-masing mempunyai informasi penting dan unik. Secara bersama- sama pertumbuhan dan kinerja keuangan memberikan diskripsi yang lebih kaya mengenai kinerja aktual dari perusahaan bila dibandingkan dengan menggunakan pengukuran secara sendirisendiri. Dimensi tolok ukur yang sering digunakan dalam mengukur kinerja usaha kecil seperti ukuran perusahaan dan kenaikan volume penjualan (Steiner and Solem, 1998; Acar, 1993; Zang 2001). Ukuran perusahaan merupakan jumlah rata-rata pekerja selama periode tertentu. Periode yang digunakan dalam mengukur kinerja usaha kecil biasanya tidak terlalu lama, dengan pertimbangan jika terlalu panjang periode yang digunakan akan memunculkan kesulitan data, terutama untuk perusahaan kecil ketersediaan data kuantitatif dan reliabilitasnya dinilai minim (Acar, 1993).

Penelitian ini juga menjelaskan hubungan antar variabel yaitu Frank (2010) menyatakan untuk menghidupkan orientasi kewirausahaan sebagai postur strategis, perusahaan membutuhkan sumber daya untuk mengembangkan dan menguji ide-ide baru, dan kemudian memposisikannya di pasar. Dalam konteks ini, modal keuangan dianggap sebagai sumber daya yang dapat digunakan secara universal. Akses keuangan berupa kredit usaha dalam dunia perbankan dapat dikelompokkan sebagai bagian dari leverage, atau suatu kebijakan yang dilakukan oleh suatu perusahaan dalam hal memperoleh sumber dana yang disertai dengan adanya beban/biaya tetap yang harus ditanggung perusahaan. Menurut Mason et al.,(2015) menyatakan bahwa leverage mempengaruhi risiko keuangan bagi perusahaan sehubungan dengan kecukupan pengembalian aset perusahaan dibandingkan dengan biaya hutang. Namun penelitian tentang dampak hutang pada kinerja perusahaan masih banyak belum disimpulkan (Fatoki, 2012), dengan beberapa penelitian menemukan dampak negatif (Eriotis et al., 2002;) sedangkan penelitian lainnya berdampak positif pada peningkatan kinerja (Negash, 2002; Hadlock dan James, 2002).

$$
\text { Mengingat bahwa orientasi }
$$

kewirausahaan memperkuat kemampuan dalam terlibat dalam perencanaan strategis, mengidentifikasi kebutuhan pelanggan dan peluang baru dan bahwa penggunaan leverage mungkin berdampak pada kinerja, akses ke pembiayaan utang dapat memainkan peran variabel yang memperkuat atau memperlemah hubungan antara orientasi kewirausahaan dan kinerja UKM. Oleh karena itu penelitian ini dapat mengasumsikan bahwa akses ke pembiayaan utang memoderasi hubungan antara orientasi kewirausahaan dan kinerja usaha.

\section{Pengaruh antar variabel Orientasi Kewirausahaan terhadap Kinerja Usaha}

Hubungan variabel antara orientasi kewirausahaan dengan kinerja usaha dijelaskan menurut beberapa peneliti terdahulu baik secara teoritis dan empiris. Mintzberg et al.,(1976) menjelaskan bahwa penyusunan strategi adalah hal penting terkait sumber daya yang digunakan, Orientasi Kewirausahaan mewakili kebijakan dan praktik yang memberikan dasar bagi keputusan dan tindakan kewirausahaan. Orientasi Kewirausahaan dipandang sebagai proses pembuatan strategi kewirausahaan yang digunakan oleh para pengusaha untuk menetapkan tujuan, mempertahankan visinya, dan menciptakan keunggulan kompetitif (Mason et al.,2015).

Kajian Orientasi Kewirausahaan dijelaskan secara awal oleh Miller (1983) wirausaha sebagai kesatuan sistem yang terlibat dalam inovasi pemasaran produk, melakukan usaha yang berisiko, dan menghasilkan inovasi serta sikap proaktif. Kemudian. Orientasi Kewirausahaan mengacu pada proses pembuatan strategi yang memberikan dasar bagi organisasi untuk keputusan dan tindakan kewirausahaan. Lumpkin dan Dess (1996) menyatakan bahwa dua dimensi tambahan penting bagi Orientasi Kewirausahaan yaitu agresivitas kompetitif dan otonomi sebagai komponen tambahan dari konstruk Orientasi Kewirausahaan. Konstruk Orientasi Kewirausahaan yang lebih kompleks menganggap dimensi yang mencurahkan energi lebih besar berasal dari komitmen pribadi, dan memiliki otonomi sebagai pengusaha.

Menurut Rodriguez (2015) menyatakan bahwa Kerjasama antar perusahaan sering dianggap sebagai opsi strategis bagi UKM dalam mengatasi keterbatasan yang dimiliki untuk meningkatkan pertumbuhan usaha Dari perspektif ini, sebuah kerja sama antar pengusaha diharapkan dapat menikmati kinerja yang lebih baik daripada UKM yang terisolasi 
(Romero, 2011). Di sisi lain, inovatif mencerminkan kecenderungan perusahaan untuk terlibat dalam ide-ide baru dan dalam proses kreatif, seperti inovasi teknologi dan pasar produk (Lumpkin dan Dess, 2001). Innovativeness sering dikaitkan dengan mencapai dan mempertahankan keunggulan kompetitif dan kinerja bisnis Lumpkin dan Dess, (1997) menyatakan bahwa mengenai konsep kinerja menunjukkan bahwa hubungannya dengan Orientasi Kewirausahaan tergantung pada indikator yang digunakan untuk menilai kinerja, namun hubungan antar keduanya tidak dapat dipisahkan. Orientasi Kewirausahaan berhubungan dengan tingkat kinerja para pelaku UMKM (Mason et al.,2015). Berdasarkan hubungan yang ada maka hipotesis dalam penelitian ini.

H1: terdapat pengaruh signifikan Orientasi Kewirausahaan terhadap Kinerja Usaha

\section{Pengaruh antar variabel Orientasi Kewirausahaan terhadap Akses Keuangan}

Frank (2010) menyatakan untuk menghidupkan orientasi kewirausahaan sebagai postur strategis, perusahaan membutuhkan sumber daya untuk mengembangkan dan menguji ide-ide baru, dan kemudian memposisikannya di pasar. Dalam konteks ini, modal keuangan dianggap sebagai sumber daya yang dapat digunakan secara universal. Akses keuangan berupa kredit usaha dalam dunia perbankan dapat dikelompokkan sebagai bagian dari leverage, atau suatu kebijakan yang dilakukan oleh suatu perusahaan dalam hal memperoleh sumber dana yang disertai dengan adanya beban/biaya tetap yang harus ditanggung perusahaan. Menurut Mason et al.,(2015) menyatakan bahwa leverage mempengaruhi risiko keuangan bagi perusahaan sehubungan dengan kecukupan pengembalian aset perusahaan dibandingkan dengan biaya hutang. Namun penelitian tentang dampak hutang pada kinerja perusahaan masih banyak belum disimpulkan (Fatoki, 2012), dengan beberapa penelitian menemukan dampak negatif (Eriotis et al., 2002;) sedangkan penelitian lainnya berdampak positif pada peningkatan kinerja (Negash, 2002; Hadlock dan James, 2002).

$$
\text { Mengingat bahwa orientasi }
$$

kewirausahaan memperkuat kemampuan dalam terlibat dalam perencanaan strategis, mengidentifikasi kebutuhan pelanggan dan peluang baru dan bahwa penggunaan leverage mungkin berdampak pada kinerja, akses ke pembiayaan utang dapat memainkan peran variabel yang memperkuat atau memperlemah hubungan antara orientasi kewirausahaan dan kinerja UKM. Oleh karena itu penelitian ini dapat mengasumsikan bahwa akses ke pembiayaan utang memoderasi hubungan antara orientasi kewirausahaan dan kinerja usaha.

Berdasarkan hubungan yang ada maka hipotesis dalam penelitian ini, yaitu:

\section{H2: terdapat pengaruh signifikan Orientasi Kewirausahaan terhadap Akses Keuangan}

\section{Pengaruh antar variabel Akses Keuangan terhadap Kinerja Usaha}

Owusu et al.,(2017) menyatakan bahwa sumber daya keuangan adalah aset organisasi yang digunakan untuk mengimbangi kewajiban dan pada saat yang sama memperoleh aset lain yang harus dimiliki perusahaan secara melimpah untuk mencapai target pertumbuhan. Meskipun demikian, teori pandangan berbasis sumber daya menganggap keuangan sebagai alat untuk pertumbuhan. Dalam teori RBV, sumber daya keuangan melengkapi manajemen strategis dengan memusatkan upaya perusahaan pada akumulasi aset. Menurut Gill and Biter (2012), keuangan yang cukup memiliki efek positif yang signifikan terhadap kelangsungan hidup dan pertumbuhan bisnis kecil dan tanpanya bisnis kecil akan sulit untuk berhasil. Ditemukan bahwa sumber daya keuangan sangat penting untuk kelangsungan hidup UKM. Namun demikian, kurangnya sumber daya keuangan oleh pengusaha sebagai kendala paling signifikan terhadap ekspansi dan pertumbuhan bisnis.

Demikian juga, Brinckmann et al. (2011) menegaskan bahwa UMKM mengalami kesulitan dalam akuisisi sumber daya keuangan untuk mengejar prospek pertumbuhan. Namun, kesulitannya adalah antara pemilik bisnis dan pemangku kepentingan eksternal terutama bank yang mengalami asimetri informasi. Kurangnya sumber daya keuangan adalah salah satu kendala terbesar yang dapat menyebabkan kematian awal sebuah bisnis kecil. Kesulitan keuangan lebih serius bagi UMKM daripada perusahaan besar. karena ketidakjelasan informasi berupa laporan keuangan harian yang menjadi ciri UMKM 
Peran utama perbankan terutama bank besar adalah untuk memberikan dukungan keuangan yang konstan kepada UMKM pada saat yang sama, karena bank dan perusahaan memiliki hubungan jangka panjang, bank dapat menawarkan saran untuk membantu UMKM berkembang (Liu et al.,2016).

Berdasarkan hubungan yang dijelaskan, sehingga penelitian ini mengembangkan hipotesis sebagai berikut:

H3 : terdapat pengaruh signifikan Akses Keuangan terhadap Kinerja Usaha

\section{METODE PENELITIAN}

Berdasarkan tujuan penelitian yang hendak dicapai, jenis penelitian ini adalah penelitian penjelasan (explanatory research) yang melakukan verifikasi atas keterkaitan seperangkat variabel dalam permasalan penelitian yang sudah ditetapkan (Indrawan dan Yaniawati, 2014). Kuesioner menggunakan skala pengukuran Likert dari 1 sampai dengan 5. Kemudian untuk mengukur orientasi kewirausahaan menggunakan dasar pengukuran dari Mason et al.,(2015) dan Lumpkin and Dess (2002) melalui 3 indikator yaitu Risk-Attitude, Proactiveness, Autonomy. Energi kompetitif. Selanjutnya untuk mengukur akses keuangan, penelitian ini mengembangkan pengukuran dari Marus et al.,(2017) dan Mason et al., (2015) dengan indikator yaitu plafon, tingkat angsuran, dan tingkat pengawasan. Sebagai variabel terikat, yaitu kinerja usaha penelitian ini menggunakan dasar pengukuran Marus et al.,(2017) dan Mason et al., (2015) dengan indikator yaitu kinerja keuangan dan kinerja non keuangan.

Total UMKM sebagai populasi penelitian yang aktif sebagai nasabah KUR BRI di Kota Blitar 958 yang berlokasi di Desa Wonodadi, Kecamatan Wonodadi, Kabupaten Blitar, dengan menggunakan rumus Yamane (1967) sehingga didapatkan jumlah sampel yaitu sebesar 91 responden UMKM yang terdiri dari tiga sektor industri yaitu peternakan, pertanian, jasa atau produksi. Penelitian ini menggunakan analisis jalur menurut Sarwono (2007), analisis jalur (path analysis) merupakan sebuah metode yang digunakan untuk melihat akibat langsung atau tidak langsung dari suatu variabel yang dihipotesiskan sebagai penyebab terhadap variabel yang diberlakukan sebagai akibat. Variabel dalam analisis jalur ini dibedakan menjadi dua yaitu eksogen yang merupakan variabel penyebab dan endogen atau variabel akibat.

Analisis jalur dilakukan untuk menemukan penjelasan-penjelasan mengenai pola-pola hubungan langsung dan tidak langsung berdasarkan pertimbanganpertimbangan teoritis serta pengetahuan dari peneliti yang ditampilkan dalam bentuk gambar (path diagram/diagram jalur) yang berfungsi membantu dalam melakukan konseptualisasi masalah yang kompleks dan mengenali implikasi empirik dan teori yang sedang diuji. Alasan dari penggunaan analisis path dalam penelitian ini yaitu ingin mengetahui pengaruh secara langsung dan tidak langsung dari tiap variabel yang akan diuji. Penelitian ini mengembangkan model konsep yang dijelaskan pada Gambar 1 berikut ini, yaitu:

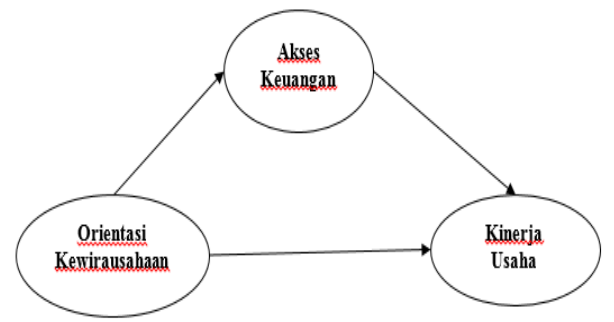

Gambar 1 : Model Penelitian

Sumber: Hasil Pengujian

\section{HASIL DAN PEMBAHASAN}

Berikut ini merupakan rangkuman hasil penelitian melalui teknik Path Analysis dengan menguji hubungan langsung dan tidak langsung yang dijelaskan pada Tabel 1.

Tabel 1 : Rangkuman Hasil Analisis Jalur

\begin{tabular}{|c|c|c|c|c|}
\hline $\begin{array}{c}\text { Hubungan } \\
\text { Variabel }\end{array}$ & $\begin{array}{c}\text { Direct } \\
\text { Effect }\end{array}$ & $\begin{array}{c}\text { Indirect Effect } \\
\text { melalui Y1 }\end{array}$ & Total Effect & $\mathrm{T}$ \\
\hline $\mathrm{X}>\mathrm{Y} 1$ & 0.6745 & & 0.6745 & 4.4569 \\
\hline $\mathrm{X} \bullet \mathrm{Y} 2$ & 0.2703 & $0.3843 ; \mathrm{F}=3.843$ & 0.6543 & 2.2264 \\
\hline $\mathrm{Y} 1 \cdot \mathrm{Y} 2$ & 0.5697 & & 0.5697 & 5.7138 \\
\hline
\end{tabular}

Sumber: Data primer diolah (2020)

\section{Hubungan Orientasi Kewirausahaan terhadap Akses Keuangan}

Penelitian ini menghasilkan hubungan positif antara orientasi kewirausahaan yang berpengaruh langsung terhadap akses keuangan. Hasil tersebut berbeda dengan penelitian Mason et al.,(2015) yang menjelaskan dukungan keuangan berupa leverage dipengaruhi oleh orientasi 
kewirausahaan. Namun, menurut penelitian Frank et al.,(2010) dan Vaznyte and Andries (2009) menjelaskan hasil penelitian yang sama bahwa orientasi kewirausahaan mengarahkan hubungan positif terhadap akses permodalan UMKM. Hasil penelitian ini menunjukkan pengaruh signifikan nilai koefisiennya yaitu 0.674 dengan $t_{\text {hitung }}$ sebesar 4.4577 dan probabilitas sebesar $0,000(\mathrm{p}<0,05)$. Artinya bahwa arah hubungan yang positif bermakna orientasi terhadap kewirausahaan yang meliputi sikap otonomi, pengambil resiko, inovasi, dan pro aktif akan meningkatkan upaya terhadap akses keuangan sebagai modal usaha.

Secara teoritis, orientasi kewirausahaan mewakili kebijakan dan praktik yang memberikan dasar bagi keputusan dan tindakan kewirausahaan. Orientasi Kewirausahaan dipandang sebagai proses pembuatan strategi kewirausahaan yang digunakan oleh para pengusaha untuk menetapkan tujuan, mempertahankan visinya, dan menciptakan keunggulan kompetitif. Sehingga berbicara tentang strategi, akses terhadap keuangan merupakan upaya untuk mencapai keunggulan bersaing. Dikarenakan secara skala UMKM akses modal keuangan adalah hal yang menjadi pembeda dengan para pesaing setingkatnya. Artinya modal keuangan yang memadai bagi suatu UMKM, akan dapat meningkatkan kinerja dengan pembelian mesin produksi, teknologi informasi, sistem manajemen yang lebih baik dan pemberdayaan karyawan yang lebih berkualitas. Terlebih lagi jika dihubungkan dengan objek penelitian yang sebagian besar adalah industri peternakan dan pertanian di Kota Blitar. Kebutuhan untuk perawatan media ternak, pakan, mesin produksi dan pemasaran membutuhkan modal yang tidak sedikit untuk peternak. Untuk para petani juga demikian, kebutuhan pupuk, perawatan harian, buruh, dan juga pemasaran menjadi orientasi yang harus dibutuhkan akses modal besar untuk mencapai keunggulan bersaing bagi petani dan peternak.

\section{Hubungan Orientasi Kewirausahaan terhadap Kinerja Usaha Pengaruh langsung orientasi} kewirausahaan terhadap kinerja usaha sejalan dengan hasil penelitian Sahoo and Yadav (2017) dan Rodriguez et al.,(2015) yang menyatakan bahwa orientasi kewirausahaan berpengaruh positif terhadap kinerja usaha dengan nilai koefisien pengaruh langsung 0,740 . Sedangkan pada penelitian ini koefisien beta sebesar 0,270 . orientasi kewirausahaan terhadap kinerja usaha, dengan $t_{\text {hitung }}$ sebesar 2,2264 dan probabilitas sebesar $0,000(\mathrm{p}<0,05)$. Arah hubungan yang positif menunjukkan bahwa semakin meningkat atau baik orientasi pelaku UMKM pada kewirausahaan akan semakin meningkatkan kinerja usaha.

Selain itu, jika dihubungkan secara teori pada kajian teoritis didasarkan pada teori $\mathrm{RBV}$, dengan alasan yaitu kajian pada UMKM yang memiliki modal intangible dalam bentuk sikap yang menjadi keunggulan kompetitif dalam bersaing. Sikap tersebut antara lain kemampuan berpikir, mengembangkan ide baru sehingga UMKM dikenal sebagai usaha dengan inovasi tingkat tinggi.

Selain itu, kecakapan dalam mengambil resiko, otonomi dan kemampuan mengambil keputusan juga menjadi aset internal bagi kelangsungan hidup UMKM. Bagian-bagian dalam intangible aset tersebut terakumulasi sebagai bentuk orientasi kewirausahaan yang bermanfaat bagi kinerja usaha. Hubungan dengan hasil penelitian ini yang menyatakan kinerja usaha dipengaruhi secara langsung oleh orientasi kewirausahaan sehingga secara teoritis RBV merupakan teori yang bermanfaat untuk dipakai sebagai kajian penelitian-penelitian dalam dunia UMKM.

Dalam prakteknya melalui program KUR BRI yang digunakan pada pengembangan UMKM, khususnya di wilayah Blitar. Hasil penelitian menunjukkan bahwa orientasi pada dunia kewirausahaan nasabah KUR BRI Unit Ponggok, Blitar ternyata positif dan signifikan. Hal tersebut berarti bahwa UMKM di Blitar memiliki perhatian lebih pada pengembangan kinerja usaha dengan mengembangkan sikapsikap pro aktif, mengambil resiko, otonomi dan inovatif.

\section{Hubungan Akses Keuangan terhadap Kinerja Usaha}

Hasil penelitian menunjukkan akses keuangan berdampak positif dan signifikan terhadap kinerja usaha. Hasil tersebut sesuai dengan penelitian Marus et al.,(2017) dengan nilai koefisien 0.543 . sedangkan pada penelitian ini, nilai koefisien menunjukkan angka 0.570 dengan $t_{\text {hitung }}$ sebesar 6.7144 dan probabilitas sebesar $0,000(p<0,05)$. Artinya bahwa semakin positif hasil dari arah hubungan tersebut 
menunjukkan bahwa akses keuangan semakin baik terhadap perannya pada peningkatan kinerja usaha.

Dalam teori RBV, sumber daya keuangan melengkapi manajemen strategis dengan memusatkan upaya perusahaan pada akumulasi aset. Faktor keuangan yang cukup memiliki efek positif yang signifikan terhadap kelangsungan hidup dan pertumbuhan bisnis kecil dan tanpanya bisnis kecil akan sulit untuk berhasil. Ditemukan bahwa sumber daya keuangan sangat penting untuk kelangsungan hidup UKM. Namun demikian, kurangnya sumber daya keuangan oleh pengusaha sebagai kendala paling signifikan terhadap ekspansi dan pertumbuhan bisnis. UMKM mengalami kesulitan dalam akuisisi sumber daya keuangan untuk mengejar prospek pertumbuhan.

Namun, kesulitannya adalah antara pemilik bisnis dan pemangku kepentingan eksternal terutama bank yang mengalami asimetri informasi. Kurangnya sumber daya keuangan adalah salah satu kendala terbesar yang dapat menyebabkan kematian awal sebuah bisnis kecil. Kesulitan keuangan lebih serius bagi UMKM daripada perusahaan besar. karena ketidakjelasan informasi berupa laporan keuangan harian yang menjadi ciri UMKM. Hasil penelitian ini menunjukkan perkembangan positif bahwa pihak eksternal dalam hal ini program KUR BRI bermanfaat untuk sebagian besar UMKM, karena memang pada misinya program KUR BRI adalah untuk meningkatkan kinerja UMKM terutama di Indonesia yang memiliki jumlah pelaku UMKM sangat besar.

\section{KESIMPULAN DAN SARAN Kesimpulan}

Hasil penelitian menunjukkan orientasi kewirausahaan berpengaruh positif dan signifikan terhadap akses keuangan yaitu KUR BRI, hasil tersebut sebagai pedoman bahwa orientasi kewirausahaan dibutuhkan oleh pelaku UMKM sebagai wadah pengembangan kualitas perilaku kewirausahaan yang berdaya saing terutama dalam hal pro aktif untuk mendapat akses keuangan. Bagian kedua, variabel orientasi kewirausahaan berpengaruh positif dan signifikan terhadap kinerja usaha, yang berarti bahwa salah satu cara untuk meningkatkan kinerja usaha pelaku UMKM adalah dengan pengembangan sikap orientasi pada bisnis, tidak hanya untuk kebutuhan sehari-hari bertahan hidup, namun bisnis UMKM yang mempunyai visi misi berkembang pesat.

Bagian ketiga, variabel akses keuangan berpengaruh positif dan signifikan terhadap kinerja usaha, yang berarti akses keuangan merupakan bagian penting dalam permasalahan UMKM, berbeda dengan perusahaan besar yang mudah mendapat pendanaan modal, untuk UMKM kendala utama adalah minimnya modal melalui akses keuangan. Sehingga hasil ini mendukung bahwa akses keuangan dapat menunjang kinerja usaha. Bagian terakhir, pengaruh tidak langsung menunjukan bahwa variabel akses keuangan berpengaruh positif sebagai mediasi antara orientasi kewirausahaan dengan kinerja usaha. Artinya bahwa akses keuangan menjadi faktor utama selain faktorfaktor lain yang menunjang kinerja usaha. Sikap pro aktif dengan mengandalkan sikap berani mengambil resiko dengan tujuan mendapat akses keuangan, misalnya program KUR BRI tentunya sangat bermanfaat bagi kinerja usaha jika memanfaatkannya dengan tepat.

Berdasarkan hasil penelitian ini, diharapkan pengembangan penelitian UMKM mengenai masalah-masalah yang selama ini dihadapi dijadikan pedoman untuk penelitian selanjutnya. Jika penelitian ini hanya berfokus pada program pemerintah yaitu KUR BRI, namun masih banyak masalah-masalah yang dihadapi dilapangan seperti daya tahan UMKM dalam bersaing, masalah teknologi yang masih sulit dikuasai, kualitas SDM yang rendah, dan juga pasar yang tidak menentu. Mengingat variabel bebas dan mediasi dalam penelitian ini merupakan hal yang penting dalam mempengaruhi kinerja usaha diharapkan hasil penelitian ini dapat dipakai sebagai acuan bagi peneliti selanjutnya untuk mengembangkan penelitian ini dengan mempertimbangkan variabel-variabel lain seperti modal sosial, inovasi, dan juga keunggulan bersaing yang merupakan variabel lain diluar variabel yang sudah masuk dalam penelitian ini.

\section{Saran}

Berdasarkan kesimpulan di atas, dapat dikemukakan beberapa saran yang diharapkan dapat bermanfaat bagi berbagai pihak. Adapun saran yang diberikan, antara lain:

1. Diharapkan pihak pemilik program KUR yaitu BRI dapat mempertahankan dan meningkatkan efektifitas KUR BRI, 
karena variabel akses keuangan mempunyai pengaruh yang signifikan terhadap kinerja usaha

2. Berdasarkan hasil penelitian ini, diharapkan pengembangan penelitian UMKM mengenai masalah-masalah yang selama ini dihadapi dijadikan pedoman untuk penelitian selanjutnya. Jika penelitian ini hanya berfokus pada program pemerintah yaitu KUR BRI, namun masih banyak masalah-masalah yang dihadapi dilapangan seperti daya tahan UMKM dalam bersaing, masalah teknologi yang masih sulit dikuasai, kualitas SDM yang rendah, dan juga pasar yang tidak menentu.

3. Mengingat variabel bebas dan mediasi dalam penelitian ini merupakan hal yang penting dalam mempengaruhi kinerja usaha diharapkan hasil penelitian ini dapat dipakai sebagai acuan bagi peneliti selanjutnya untuk mengembangkan penelitian ini dengan mempertimbangkan variabel-variabel lain seperti modal sosial, inovasi, dan juga keunggulan bersaing yang merupakan variabel lain diluar variabel yang sudah masuk dalam penelitian ini.

\section{DAFTAR PUSTAKA}

Arikunto, S. (2012). Prosedur Penelitian : Suatu Pendekatan Praktik (Edisi Revisi). In Rineka Cipta.

Baker, W. E., \& Sinkula, J. M. (2009). The complementary effects of market orientation and entrepreneurial orientation on profitability in small businesses. Journal of Small Business Management.

https://doi.org/10.1111/j.1540-

627X.2009.00278.x

Barney, J. (1991). Firm Resources and Sustained Competitive Advantage. Journal of Management. https://doi.org/10.1177/01492063910170 0108

Depkop. (2018). Perkembangan Data Usaha Mikro, Kecil, Menengah Dan Usaha Besar. Www.Depkop.Go.Id.

Eton, M. (2019). Credit Financing and Performance of SMEs in Lira Municipality, Uganda Credit Financing and Performance of SMEs in Lira Municipality, Uganda. 8(January), 121127.

Fatoki, O. (2012). The Impact of Entrepreneurial Orientation on Access to Debt Finance and Performance of Small and Medium Enterprises in South Africa. Journal of Social Sciences. https://doi.org/10.1080/09718923.2012.1 1893058

Frank, H., Kessler, A., \& Fink, M. (2010). Entrepreneurial Orientation and Business Performance - A Replication Study. Schmalenbach Business Review. https://doi.org/10.1007/bf03396804

Ghozali, I. (2011). Moderated Structural Equation Modeling. In Model persamaan struktural. Konsep dan aplikasi dengan program AMOS 19.0.

Hadlock, C. J., \& James, C. M. (2002). Do banks provide financial slack? Journal of Finance. https://doi.org/10.1111/15406261.00464

Hartono, H., \& Hartomo, D. D. (2016). FAKTOR-FAKTOR YANG MEMPENGARUHI PERKEMBANGAN UMKM DI SURAKARTA. Jurnal Bisnis Dan Manajemen. https://doi.org/10.20961/jbm.v14i1.2678

Huang, S. K., \& Wang, Y. L. (2011). Entrepreneurial orientation, learning orientation, and innovation in small and medium enterprises. Procedia - Social and Behavioral Sciences, 24, 563-570. https://doi.org/10.1016/j.sbspro.2011.09. 004

Jimenéz-jimenéz, D., Martínez-costa, M., \& Sanz-valle, R. (2013). Innovation, organizational learning orientation and reverse knowledge transfer in multinational companies. Electronic Journal of Knowledge Management.

Khotimah, K. (2013). F utur E :PANDANGAN BERBASIS SUMBER DAYA (RBV) DALAM PEMBAHASAN ORGANISASI EKONOMI. : : Jurnal Manajemen Dan Akuntansi.

Kotler, P., \& Keller, K. L. (2009). Marketing management (13th ed.). In Prentice Hall.

Kundid, A., \& Ercegovac, R. (011). Credit 
rationing in financial distress: Croatia SMEs' finance approach. International Journal of Law and Management. https://doi.org/10.1108/17542431111111 890

Liu, Y., Fujiwara, K., Jinushi, T., \& Yamori, N. (2016). How Should Banks Support SMEs to Manage Funding Risks in China? The Role of Relationship Banking. In Risk Management in Emerging Markets. https://doi.org/10.1108/978-1-78635-452520161025

Lumpkin, G. T., \& Dess, G. G. (1996). Clarifying the entrepreneurial orientation construct and linking it to performance. Academy of Management Review. https://doi.org/10.5465/AMR.1996.96021 61568

Mason, M. C., Floreani, J., Miani, S., Beltrame, F., \& Cappelletto, R. (2015). Understanding the Impact of Entrepreneurial Orientation on Smes' Performance. the Role of the Financing Structure. Procedia Economics and Finance, 23(October 2014), 1649-1661. https://doi.org/10.1016/s22125671(15)00470-0

McDermott, C. M., \& Prajogo, D. I. (2012). Service innovation and performance in SMEs. International Journal of Operations and Production Management, 32(2), 216-237. https://doi.org/10.1108/01443571211208 632

Miller, W. L. (2001). Innovation for business growth. Research Technology Management.

https://doi.org/10.1080/08956308.2001.1 1671451

Morris, M., \& Lewis, P. (1995). The determinants of entrepreneurial activity: Implications for marketing. European Journal of Marketing. https://doi.org/10.1108/03090569510094 991

Narver, J. C., \& Slater, S. F. (1990). The Effect of a Market Orientation on Business Profitability. Journal of Marketing. https://doi.org/10.2307/1251757

Nazir, M. (2005). Metode Penelitian, Ghalia Indonesia. Nuraini R, EKa.
Negash, M. (2002). Corporate tax and capital structure: some evidence and implications. Investment Analysts Journal.

https://doi.org/10.1080/10293523.2002.1 1082439

Owusu, J., Hassan, M., Ismail, M. B., \& Latif, A. A. B. A. (2017). A Conceptual Framework for Financing SME Growth in Ghana. European Journal of Business and Management.

Parkman, I. D., Holloway, S. S., \& Sebastiao, H. (2012). Creative industries: Aligning entrepreneurial orientation and innovation capacity. Journal of Research in Marketing and Entrepreneurship, 14(1), 95-114. https://doi.org/10.1108/14715201211246 823

Rodríguez-Gutiérrez, M. J., Moreno, P., \& Tejada, P. (2015). Entrepreneurial orientation and performance of SMEs in the services industry. Journal of Organizational Change Management. https://doi.org/10.1108/JOCM-01-20150020

Rosenbusch, N., Brinckmann, J., \& Bausch, A. (2011). Is innovation always beneficial? A meta-analysis of the relationship between innovation and performance in SMEs. Journal of Business Venturing, 26(4), 441-457. https://doi.org/10.1016/j.jbusvent.2009.1 2.002

Sahoo, S., \& Yadav, S. (2017). Entrepreneural orientation of SMEs, total quality management and firm performance. Journal of Manufacturing Technology Management.

https://doi.org/10.1108/JMTM-04-20170064

Schumpeter, J., \& Backhaus, U. (2006). The Theory of Economic Development. $\mathrm{n}$ Joseph Alois Schumpeter. https://doi.org/10.1007/0-306-48082-4_3

Sekaran, U., \& Bougie. (2017). Metode Penelitian untuk Bisnis Pendekatan Pengembangan-Keahlian. In Metode Penelitian untuk Bisnis Pendekatan Pengembangan-Keahlian.

Singarimbun, M. (2006). sofian Effendi. In 
Metode Penelitian Survai.

Sugiyono, P. D. (2010). Metode Penelitian Bisnis. Pendekatan Kuantitatif, kualitatif dan R \& D. In Bandung: Alfabeta.

Swierczek, F. W., \& Ha, T. T. (2003). Entrepreneurial Orientation, Uncertainty Avoidance and Firm Performance: An Analysis of Thai and Vietnamese SMEs. Entrepreneurial Orientation, Uncertainty Avoidance and Firm Performance: An Analysis of Thai and Vietnamese SMEs. https://doi.org/10.5367/00000000310129 9393

Terziovski, M. (2010). Research notes and commentaries innovation practice and its performance implications in small and medium enterprises (SMEs) in the manufacturing sector: A resource-based view. In Strategic Management Journal. https://doi.org/10.1002/smj.841

Undang-Undang No. 20 Tahun 2008. (2008). Tentang: Usaha,Mikro,Kecil dan Menengah. Sekretariat Negara. Jakarta.

Vaznyte, E., \& Andries, P. (2019). Entrepreneurial orientation and start-ups' external financing. Journal of Business Venturing, 34(3), 439-458. https://doi.org/10.1016/j.jbusvent.2019.0 1.006

Weerawardena, J. (2003). Exploring the role of market learning capability in competitive strategy. European Journal of Marketing. https://doi.org/10.1108/03090560310459 023

Yeh-Yun Lin, C., \& Yi-Ching Chen, M. (2007). Does innovation lead to performance? An empirical study of SMEs in Taiwan. Management Research News. https://doi.org/10.1108/01409170710722 955

Zulkiffli, S. N. 'Atikah, \& Perera, N. (2012). A Literature Analysis on Business Performance for SMEs: Subjective or Objective Measures? SSRN Electronic Journal.

https://doi.org/10.2139/ssrn.1867874 